\title{
Targeting abundant survivin expression in liposarcoma: subtype dependent therapy responses to YM155 treatment
}

\author{
Christian Vay ${ }^{1}$. Philipp M. Schlünder ${ }^{1}$. Levent Dizdar ${ }^{1}$. Irene Esposito ${ }^{2}$ Markus P. H. Ghadimi ${ }^{3}$. \\ Wolfram T. Knoefel ${ }^{1} \cdot$ Andreas Krieg $^{1}$ (i)
}

Received: 11 August 2021 / Accepted: 25 November 2021 / Published online: 3 December 2021

(c) The Author(s) 2021

\begin{abstract}
Purpose Liposarcoma (LPS) represent the largest group of malignant soft tissue tumours comprising a heterogeneous group of subtypes in which the degrees of chemoresistance and radiosensitivity strongly vary. Consequently, it is of utmost interest to establish novel therapeutic regimens based on molecular targets.

Methods Immunohistochemical staining of survivin was performed in tissue microarrays comprising 49 primary LPS specimens. LPS cell lines were treated with survivin antagonist YM155 and doxorubicin or etoposide alone as well as in combination. Changes in cell viability were investigated and the synergistic effect of a combined therapy analysed.

Results Immunohistochemistry revealed an abundant expression of survivin in LPS that significantly concurred with lessdifferentiated tumour subtypes and grading. In vitro, we demonstrated the impact of the survivin inhibitor YM155 on dedifferentiated LPS (DDLPS) and, even more imposing, pleomorphic LPS (PLS) tumour cell viability with a strong induction of apoptosis. A combined treatment of doxorubicin or etoposide with YM155 augmented the cytotoxic effects on DDLPS and PLS cells.

Conclusion These findings support the significant role of survivin in the oncogenesis and progression of LPS subtypes providing a rationale to target survivin in eligible in-vivo models and to pioneer clinical applications of survivin-specific substances unfolding their therapeutic potential in LPS patients prospectively.
\end{abstract}

Keywords Liposarcoma $\cdot$ Survivin · Inhibitor of apoptosis protein · Targeted therapy $\cdot$ Apoptosis

\section{Introduction}

Liposarcoma (LPS) is among the most frequent types of soft tissue sarcoma with $50 \%$ of retroperitoneal localisation and 25\% peripheral distribution (Crago and Brennan 2015).

Complete surgical resection is the central therapeutic approach towards all four main groups of LPS-well

Andreas Krieg

andreas.krieg@med.uni-duesseldorf.de

1 Department of Surgery (A), Heinrich-Heine-University and University Hospital Duesseldorf, Moorenstr. 5, Bldg. 12.46, 40225 Duesseldorf, Germany

2 Institute of Pathology, Heinrich-Heine-University and University Hospital Duesseldorf, Moorenstr. 5, 40225 Duesseldorf, Germany

3 Department of General, Visceral, Tumour, and Transplant Surgery, University of Cologne, Kerpener Strasse 62, 50931 Cologne, Germany differentiated (WDLPS) and dedifferentiated liposarcomas (DDLPS) accounting for 60\% of LPS cases, myxoid or round cell liposarcoma (MLPS) amounting to $20-30 \%$ (de Graaff et al. 2017), and pleomorphic liposarcoma (PLS) adding 5\% to the total of LPS occurrences (Crago and Dickson 2016).

Sharing their fate of significant recurrence levels and a perspective of limited patient survival after surgery in a serious proportion of LPS patients, the various subtypes differ with regard to their biological attributes (Dalal et al. 2006; Lee et al. 2018). WDLPS with recurrence-free 5-year survival rates ranging from 93 to $100 \%$ (Kooby et al. 2004) often harbour 12q13-15 amplifications incorporating the MDM2 and CDK4 oncogenes. With more complex genomic aberrations frequently altering chromosomes 3, 11, and 19 (Crago et al. 2012), DDLPS stands out with a disease-specific 5-year-survival of $44 \%$. MLPS are associated with a FUS-DDIT3 fusion protein acting as an aberrant transcription factor after frequent $\mathrm{t}(12 ; 16)$ translocation. As $30-50 \%$ of PLS patients develop local tumour relapse and up to $50 \%$ 
of the cases prone for metastasis frequently evince losses of TP53 and $R b$, these frequent genetic aberrations remain difficult to be utilised therapeutically.

While surgery remains the primary therapeutic approach in all LPS entities, adjuvant treatment approaches strongly vary among the four subtypes due to significant differences in their susceptibility to adjuvant or neoadjuvant treatment regimens (Crago and Dickson 2016). Though their primaries are initially receptive for radio- and chemotherapy, even MLPS may recur with local relapse or systemic spread in up to $40 \%$ of the cases as reflected in considerably reduced survival rates (de Graaff et al. 2017). Whereas PLS appear partly chemosensitive, clinically DDLPS are frequently resistant to chemo- and radiotherapies or show only minor prognostic benefits (Italiano et al. 2012). Accordingly, the outcome of recurrent DDLPS remains extremely poor (Anaya et al. 2009; Park et al. 2009).

Despite the proven antiproliferative and cytotoxic properties of anthracyclines, alkylating agents, and topoisomerase inhibitors in several subtypes of LPS, undesirable side effects frequently occur and, as in other entities, tumour cell resistance develops during malignant progression providing only minor improvements of patient survival (Lee et al. 2017). For this reason, conventional systemic therapy components are sought to be potentiated by specifically targeting molecular pathways involved in cell proliferation and cell survival (Lee et al. 2018). While genomic alterations have been extensively investigated in soft tissue sarcoma and several substances have demonstrated their principal effectiveness in vitro (Barretina et al. 2010; Crago et al. 2016), none of these agents has been implemented in LPS treatment schemes so far.

As a substantial player in mitosis and programmed cell death, survivin is a promising candidate to contribute to the advancement of systemic LPS therapy and has been extensively reviewed recently by Wheatly and Altieri (Wheatley and Altieri 2019). Among the five members of the inhibitor of apoptosis (IAP) family of multifunctional proteins, survivin is a highly conserved eukaryotic protein exerting its anti-apoptotic and mitotic activities in cytoplasm, mitochondria, and nuclei. Binding to the aurora B kinase, survivin contributes to the formation of the chromosomal passenger complex safeguarding the segregation of paired chromatid during mitosis. When XIAP is intercepted by survivin in the cytoplasm, caspase-9 inhibition blocks the activation of the apoptotic pathway. Simultaneously, survivin stimulates cell motility by the upregulation of $\alpha 5$-integrins (Wheatley and Altieri 2019).

Physiologically expressed by proliferating cells during embryonal development and active in non-neoplastic adult thymic and placenta tissue only, survivin meets a central criterion for targeted tumour therapies as it is upregulated and overexpressed by most malignancies (Kanwar et al.
2013). Therefore, it has been considered as an oncotherapeutic target since its first description in 1997 (Ambrosini et al. 1997; Peery et al. 2017). As the expression of survivin has demonstrated its oncogenic and metastasis-enhancing potential, and, consequently, its prognostic relevance in several solid epithelial and endocrine malignancies (Mahotka et al. 2002; Span et al. 2004; Byun et al. 2007; McKenzie and Grossman 2012; Krieg et al. 2013a, 2013b; Werner et al. 2016, 2017; Brany et al. 2017; Dizdar et al. 2017a, 2017b, 2018), it has also been established as a relevant player in sarcoma formation and progression (Kappler et al. 2003; Ghadimi et al. 2011, 2012; Hingorani et al. 2013; Lusby et al. 2013; de Graaff et al. 2017). First hints that survivin might play a role in the tumour biology of LPS have been proposed by a study demonstrating abundant expression of survivin in PLS and MLPS specimens (Ghadimi et al. 2011; de Graaff et al. 2017). However, the biological and prognostic role of survivin still remains to be elucidated in all subtypes of LPS. Thus, the aim of our study was to shed light on the relevance of survivin as a biomarker according to the "REporting Recommendations for Tumour MARKer Prognostic Studies (REMARK)" and to further evaluate its role as therapeutic target in LPS.

\section{Material and methods}

\section{Patients}

The study was approved by the local ethics committee at the Medical Faculty of the Heinrich-Heine-University Duesseldorf, Germany (institutional board review no. 3821), and carried out in accordance with good clinical practice and the Declaration of Helsinki (World Medical Association 2013). Each of the patients underwent tumour resection for primary LPS at the University Hospital Duesseldorf, Germany, in between 2001 and 2014. The tumours were staged and graded by pathologists according to the 8 th edition of the TNM-classification recommended by the International Union Against Cancer (UICC) and World Health Organization (WHO). Tumours in which pathological staging was based on older TNM editions where re-classified according to the 8th edition. Follow-up data was collected until all experiments had been completed and overall survival was determined as the period from the date of surgery until the date of the last follow up or death of any cause. Patients with stage I-IV disease independently of the tumour localisation, neoadjuvant therapy and microscopic resection margin status who received surgery with curative intend were included in this study. Patients who had received only palliative chemotherapy after histological confirmation of LPS, who had deceased perioperatively within 30 days after surgery, or who had been lost to follow up were excluded from the 
study. Clinicopathological details were collected retrospectively from original pathological reports and patient case files. Follow-up data were retrieved before reviewing the experimental results.

\section{Tissue microarray and immunohistochemistry}

Five tissue microarrays (TMA) were constructed from formalin-fixed and paraffin-embedded specimens comprising 49 samples of primary liposarcoma complemented by 15 lipomas, 13 samples from normal fatty tissue, and samples from other organs serving as positive controls (Packeisen et al. 2003), all of which originated from the Institute of Pathology, University Hospital Duesseldorf, Germany, where all cases had been reviewed by board-certified pathologists. A TMA contained two cylindrical specimens for each tumour sample from a donor block, five extracts from lipoma samples, five cylinders from normal fatty tissue, and three specimens deriving from other tissue types.

After preparing tissue sections with a thickness of $4 \mu \mathrm{m}$ from the TMA, immunohistochemical staining was performed using the ZytoChem Plus HRP-DAB Kit (Zytomed Systems, Berlin, Germany) as described previously (Werner et al. 2016). In brief, after deparaffinisation and rehydration, epitope demasking was carried out at $95^{\circ} \mathrm{C}$ for $30^{\prime}$ using a $3 \%$ trisodium citrate dihydrate buffer equilibrated at $\mathrm{pH}$ 6.0, followed by cooling for 20' to room temperature. Incubation of the tissue sections in $3 \% \mathrm{H}_{2} \mathrm{O}_{2}$ phosphate-buffered saline (PBS, $\mathrm{pH}$ 7.4) for 10' blocked endogenous peroxidase before the slides were rinsed three times for 2' in PBS with 0.1\% Tween-20 (Sigma-Aldrich, St. Louis, MO, USA). After blocking reagent was added to the sections for 10' to block unspecific binding sites minimising background staining, the slides were washed in PBS with $0.1 \%$ Tween-20. Incubation with the rabbit primary polyclonal anti-survivin antibody (NB500-201; 1:750 dilution; Novus, Littleton, CO, USA), took 60' at room temperature. Isotype controls with rabbit immunoglobulin fraction (Code X0903; 1:1,000 dilution; Dako, Glostrup, Denmark) served as negative controls. After triple rinsing the slides in PBS with 0.1\% Tween-20, the sections were incubated with biotinylated secondary antibody and streptavidin-HRP conjugate, before 3,30-diaminobenzidine high contrast was added for 10' in darkness resulting in epitope visualisation. Finally, tissue sections were counterstained with Mayer's haematoxylin. Human colonic and tonsillar tissue specimens had been positively pretested for survivin expression served as positive controls.

Survivin staining intensities and percentage of chromogen positive cells were scored by two independent investigators according to the immunoreactivity score (IRS) reported by Remmele and Stegner (1987) without knowledge of histopathological parameters or patient survival outcome. Both investigators were experienced in the visual assessment and evaluation of the IRS. Differing ratings resulted in a reexamination of the respective samples by both investigators until a consensual scoring was reached.

\section{Cell culture}

While the cell line Lipo-DUE1 was cultivated in RPMI 1640 Medium GlutaMax ${ }^{\mathrm{TM}}$ as previously described (Mersch et al. 2016), DDLPS cell line Lipo246A and PLS cell line PLS-1 kindly provided by Dina Lev (MTA No. MT2012-10,265) were maintained in DMEM $1 \times$ GlutaMax $^{\text {TM }}$ (both obtained from Gibco Life Technologies, Carlsbad, CA, USA). Both media were supplemented with $10 \%$ heat inactivated bovine FCS (Gibco Life Technologies, Carlsbad, CA, USA), penicillin, and streptomycin (both obtained from Biochrom $\mathrm{GmbH}$, Berlin, Germany) to be kept in an atmosphere with $5 \% \mathrm{CO}_{2}$ at $37^{\circ} \mathrm{C}$. Cells were passaged routinely within seven days at a confluence of $80 \%$ by trypsinisation with $0.05 \%$ Trypsin/EDTA (Gibco Life Technologies, Carlsbad, CA, USA) and after washing with PBS (Gibco Life Technologies, Carlsbad, CA, USA).

\section{RNA quantification by real-time PCR}

Total RNA was extracted from PBS washed LPS cells by RNeasy Mini Kits (Qiagen GmbH, Hilden, Germany) and concentrations were determined with the Infinite ${ }^{\circledR}$ M200 microplate reader (Tecan Group Ltd., Mannedorf, Switzerland). After $5 \mu \mathrm{g}$ of total RNA per sample were incubated with $0.5 \mu \mathrm{g}$ Oligo(dT) 18 Primer (Thermo Fisher Scientific, Waltham, MA, USA) for $10^{\prime}$ at $65^{\circ} \mathrm{C}$, cDNA was synthesized in $7 \mu \mathrm{l}$ from a master mix of $0.5 \mu \mathrm{l}$ Transcriptor Reverse Transcriptase, $4 \mu \mathrm{l}$ Transcriptor RT Reaction Buffer $5 \times$ concentrated, $5 \mu \mathrm{l}$ Protector RNase Inhibitor, and $2 \mu \mathrm{l}$ dNTP Mix (Roche Diagnostics GmbH, Mannheim, Germany) for $30^{\prime}$ at $55^{\circ} \mathrm{C}$ before the reverse transcriptase was inactivated for $5^{\prime}$ at $85^{\circ} \mathrm{C}$. After adjusting the cDNA concentrations to $2.5 \mathrm{ng} / \mu \mathrm{l}$, triplicates from $2.5 \mu \mathrm{l}$ of cDNA were mixed each with $12.5 \mu$ l FastStart TaqMan ${ }^{\circledR}$ Probe Master (Roche Diagnostics $\mathrm{GmbH}$, Mannheim, Germany), $0.25 \mu$ probe solution (probe 11 and probe 60) from the Human Universal Probe Library Set (Roche Diagnostics GmbH, Mannheim, Germany) and $0.25 \mu \mathrm{l}$ of forward (survivin: 5' GCC CAG TGT TTC TTC TGC TT 3'; GAPDH: 5' GCC CAG TGT TTC TTC TGC TT $3^{\prime}$ ) and reverse primers (survivin: $5^{\prime}$ AAC CGG ACG AAT GCT TTT TA 3'; GAPDH: 5' GCC CAA TAC GAC CAA ATC C $3^{\prime}$ ) for quantitative real-time-PCR (survivin primers: Eurofins Scientific, Luxemburg, Luxemburg; GAPDH primers: Roche Diagnostics GmbH, Mannheim, Germany). GAPDH was used as internal reference gene. qPCR runs were conducted with the Chromo4 detector on a Dyad Disciple thermal cycler (Bio-Rad Laboratories Inc., Hercules, CA, USA) with $95{ }^{\circ} \mathrm{C}$ for $10^{\prime}$, followed by 
40 cycles of denaturation at $95^{\circ} \mathrm{C}$ for $15^{\prime \prime}$ and annealing and extension at $60^{\circ} \mathrm{C}$ for $1^{\prime}$. RNA expression values were calculated in relation to GAPDH and qPCR Human Reference Total RNA (Stratagene, La Jolla, CA, USA) in accordance with the $2^{-\Delta \Delta C T}$-method as published by Livak and Schmittgen (2001).

\section{Flow cytometry}

LPS cells were prepared for FACS analyses using the Molecular Probes FITC Annexin V/Dead Cell Apoptosis Kit (Thermo Fisher Scientific, Waltham, MA, USA). After treatment with YM155 (Selleck Chemicals LLC, Houston, TX, USA) in three different concentrations ( $30 \mathrm{nM} ; 100 \mathrm{nM}$; $300 \mathrm{nM}$ ) for $48 \mathrm{~h}, 1 \times 10^{6}$ cells were washed in PBS and transferred to FACS vials (BD Biosciences, San Jose, CA, USA) before passing through the flow cytometry process in the BD FACSCanto ${ }^{\mathrm{TM}}$ device (BD Biosciences, San Jose, CA, USA) according to the manufacturer's protocol. Cells were gated depending on the detected FITC-annexin and propidium iodide intensities, among which the double-positive cells were attributed to the apoptotic cell faction.

\section{Functional in vitro assays}

MTS assays for cell viability were analysed in 96-well culture plates with $1 \times 10^{4}$ LPS cells seeded per well. After $24 \mathrm{~h}$ of cultivation as described above, cells were treated with various compound concentrations ( $30 \mathrm{nM} ; 100 \mathrm{nM} ; 300 \mathrm{nM}$ ) of YM155 (Selleck Chemicals LLC, Houston, TX, USA), doxorubicin (AppliChem GmbH, Darmstadt, Germany), etoposide (Merck KGaA, Darmstadt, Germany), or dimethyl sulfoxide (DMSO; Gibco Life Technologies, Carlsbad, CA, USA) in a minimum of three wells for $96 \mathrm{~h}$, respectively. The CellTiter $96^{\circledR}$ AQueous Non-Radioactive Cell Proliferation Assay (Promega Corporation, Madison, WI, USA) was used to measure cell viability. All experiments were performed in triplicates and the mean $\mathrm{IC}_{50}$ was obtained based on the results of three independent experiments. For combinated treatment assays, the fractional products (FP) were determined as described by Webb (Webb 1963) with FP values $<1$ representing synergistic effects, values $=1$ additive effects, and values $>1$ antagonistic effects.

Cell proliferation was determined by BrdU incorporation using a cell proliferation ELISA BrdU assay (Roche Diagnostics GmbH, Mannheim, Germany). Both assays were conducted according to the manufacturers' protocols. Absorbances were measured with the Infinite ${ }^{\circledR}$ M200 microplate reader (Tecan Group Ltd., Mannedorf, Switzerland), whereby absorbance values of YM155 treated cells were recorded as proportional to the absorbance of the corresponding DMSO treated control cells.

\section{Western blot analysis}

$1 \times 10^{5}$ cultivated cells were harvested, washed in PBS, and transferred to $25 \mathrm{~cm}^{2}$ cell culture flasks for $24 \mathrm{~h}$ before being treated with YM155 (Selleck Chemicals LLC, Houston, TX, USA) or DMSO (Gibco Life Technologies, Carlsbad, CA, USA) for another $24 \mathrm{~h}$. Then, cells were lysed in RIPA lysis buffer (Merck KGaA, Darmstadt, Germany) and incubated with protease inhibitor mix (cOmplete, Roche Diagnostics, Basel, Switzerland). Protein lysates were separated on SDS-PAGE gels and blotted to nitrocellulose membranes (Thermo Fisher, Waltham, MA, USA) which were blocked with TBS-T buffer containing 5\% soluble nonfat dry milk (Nestlé, Vevey, Switzerland). After incubation with antisurvivin primary antibody (NB500-201; 1:1,000 dilution; Novus, Littleton, CO, USA) for $16 \mathrm{~h}$ at $4{ }^{\circ} \mathrm{C}$ and rinsing in TBS-T buffer, anti-rabbit IgG secondary antibody (HRPlinked Antibody \#7074; 1:1,000 dilution; Cell Signalling Technology, London, UK) was added and incubated with $1.3 \mu \mathrm{l}$ of Precision Protein ${ }^{\mathrm{TM}}$ StrepTactin-HRP (Bio-Rad Laboratories, Inc., Hercules, CA, USA) for $1 \mathrm{~h}$. GAPDH as a loading control was detected by primary mouse antiGAPDH antibody (Clone 6C5; 1:5,000 dilution; Abcam, Cambridge, UK) and marked by goat anti-mouse IgG (H\&L (HRP); 1:5,000 dilution; Abcam, Cambridge, UK). Membranes were washed again in TBS-T buffer and developed with the Clarity Max ${ }^{\mathrm{TM}}$ Western ECL Substrate (Bio-Rad Laboratories, Inc., Hercules, CA, USA) and visualised with the VersaDoc Imaging System (Bio-Rad Laboratories $\mathrm{GmbH}$, Munich, Germany). One representative western blot was selected for presentation after experiments were repeated thrice.

\section{Statistical analysis}

Survivin protein expression in immunohistochemical stained TMAs was assessed by immunoreactivity scores (IRS) according to Remmele and Stegner (1987) and categorized into high (IRS $\geq 3$ ) or low (IRS $<3$ ) levels of expression according to the median IRS for survivin expression in all investigated LPS tissue samples. Correlations between nonparametrical data sets were analysed using the paired t-test, Mann-Whitney-U test, Kruskal-Wallis test, or Dunn-Bonferroni test as indicated.The Fisher's exact test, Cramér's V, or, whenever appropriate, the Chi-square test were applied for categorical data. The correlation of numerical data with clinicopathological variables were examined applying the Mann-Whitney-U test. Kaplan-Meier curves were compiled and analysed using the log-rank test (Mantel-Cox). Variables with a $p$ value $<0.05$ by univariate analysis were included 
in a multivariate Cox regression model using a backward selection. Computed analyses were conducted employing GraphPad Prism for Windows (version 5; GraphPad Software Inc., La Jolla, CA, USA), Microsoft Excel (version 14; Microsoft Corp., Redmond, WA, USA) and SPSS statistics for Windows (version 17.0; SPSS Inc., Chicago, IL, USA). A $p<0.05$ was defined to indicate a statistically significant difference. Cramér's $V$ values of $<0.2$ were interpreted as weak correlations, values $\geq 0.2-0.5$ as moderate, and values $>0.5$ as strong correlations.

\section{Results}

\section{Primary liposarcoma—patients and outcome}

According to our selection criteria, 49 samples from patients with primary LPS were included in the present study after undergoing surgical resection at our department between 2001 and 2014. The baseline characteristics of the included patients are summarized in Table 1. Patients' median overall survival (OS) time was 41 months (range 4-146 months) resulting in a 5-year OS of 52.6\%. At the end of follow-up $31(63.3 \%)$ patients were still alive with a median follow-up time of 68 months (range 6-146 months).

Assessing the clinicopathologic parameters statistically, LPS affecting the deep soft tissue in the abdomen and retroperitoneum, which was to be distinguished from LPS localised within the superficial soft tissue of the head, extremities, or thorax, correlated with LPS subtypes PLS/ DDLPS ( $p=0.037$; Cramér's $V=0.417$ ), higher tumour grade ( $p=0.037$; Cramér's $V=0.417)$ and larger primary tumour size (T3/4) ( $p=0.016$; Cramér's $V=0.344)$.

\section{Primary liposarcoma—survivin expression}

After immunohistochemical staining, the IRS for survivin was assessed and the median IRS of 3 was defined as a cutoff to differentiate high from low expression. In contrast to the distinct LPS subtypes, survivin expression was undetectable in 13 fatty tissue samples and in 15 lipomas (Fig. 1A-F) [ $p<0.001$; Cramérs $V=0.655]$.

Whereas $83.3 \%$ of WDLPS samples demonstrated a low survivin expression, the remaining LPS subtypes (DDLPS $100 \%$, MLPS $94.1 \%$, PLS 100\%) presented with exclusively or predominantly high expression (Table 2). Of note, high survivin expression levels also significantly correlated with higher grading (G2-3). In addition, when comparing the IRS as numeric variable across groups for each clinicopathological variable, we confirmed the association between survivin expression levels and LPS subtype or tumour grade (Fig. 1G-J).
Table 1 Patient characteristics $(n=49)$

\begin{tabular}{ll}
\hline Variables & No. of patients $(\%)$ \\
\hline Total & 49 \\
Age & \\
Median (range); years & $58(29-93)$ \\
Gender & \\
Male & $29(59.2)$ \\
Female & $20(40.8)$ \\
Localisation & \\
Head & $1(2)$ \\
Extremeties & $21(42.9)$ \\
Thorax & $4(8.2)$ \\
Abdomen & $8(16.3)$ \\
Retroperitoneum & $15(30.6)$ \\
Subtype & \\
WDLPS & $18(36.7)$ \\
MLPS & $17(34.7)$ \\
PLS & $5(10.2)$ \\
DDLPS & $9(18.4)$ \\
Grade & \\
G1 & $23(46.9)$ \\
G2 & $10(20.4)$ \\
G3 & $13(26.5)$ \\
Undefined & $3(6.1)$ \\
Tumour stage 1 & \\
T2 & $10(16.3)$ \\
T3 & $18(36.7)$ \\
T4 & $8(16.3)$ \\
Median (range); cm & $15(30.6)$ \\
Neoadjuvant therapy & \\
No & \\
Unknown & \\
\hline
\end{tabular}

Next, we investigated whether survivin expression and clinicopathological variables were associated with patients' overall survival. Thereby, we created Kaplan-Meier survival curves and performed survival analysis using log rank analysis as well as a Cox regression model (Fig. 2, Table 3).

Accordingly, univariate analysis revealed that high survivin expression (IRS $\geq 3$ ) correlated with a shorter overall survival for patients with high expression levels of survivin in the tumour (HR 5.307, CI 1.215-23.192, $p=0.027$ ) (Table 3). In addition, LPS subtype was identified as a prognostic parameter (HR 1.960, CI 1.289-2.980, $p=0.002)$. Moreover, high grade tumours (G2/3) (HR 6.389, CI 1.825-22.364, $p=0.004)$ and advanced T stages (T3-4) (HR 4.063, CI 1.437-11.490, $p=0.008$ ) were significantly associated with patients' prognosis. 


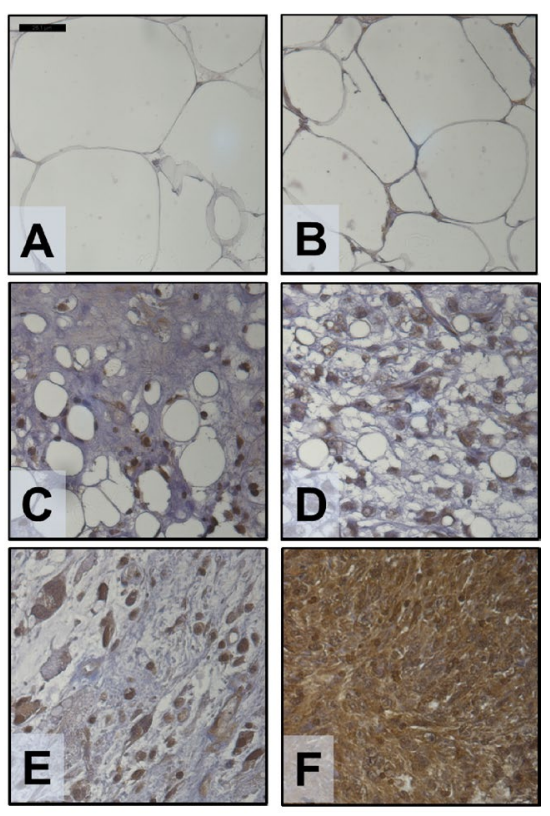

Fig. 1 Expression of survivin in liposarcoma (LPS). Representative images after immunohistochemistry for survivin expression (DAB counterstained with Mayer's haematoxylin) on tissue-microarrays (TMA) from A fatty tissue, B lipoma, C WDLPS, D MLPS, E PLS, and $\mathbf{F}$ DDLPS. Images were captured at $400 \mathrm{fold}$ magnification (scale bar indicates $25 \mu \mathrm{m}$ ). IRS distribution of survivin expression (statistical significances as indicated by asterisks): G While low $(<3)$ survivin expression was preponderant only in WDLPS, DDLPS, MLPS, and PLS shared significantly higher expression scores $(\geq 3)$. H Low

Multivariate analysis finally identified the primary tumour depth (T stage) (HR 4.391, CI 1.479-13.036, $p=0.008$ ) and tumour subtype (HR 2.257, 1.380-3.691, $p=0.001$ ) as independent prognostic markers for the assessed cohort of primary LPS (Table 3).

\section{In-vitro effects of survivin in liposarcoma cells}

To explore the biological role of survivin in LPS, we first analysed the base line expression in liposarcoma cell lines Lipo-DUE1 (DDLPS), Lipo246A (DDLPS), and.

PLS-1 (PLS) by quantitative RT-PCR and western blot (Fig. 3A, B). While Lipo-DUE1 cells showed a significantly higher RNA expression with a mean $2^{-\Delta \Delta C T}$ of $5.86 \pm 2.47$ ( $p=0.0001$; Kruskal-Wallis test), the protein expression in the cell line was comparatively weak. In contrast, PLS-1 as well as Lipo246A cells exhibited lower mean RNA expression levels of $0.73 \pm 0.32$ and an intermediate RNA-level amounting to $2.63 \pm 1.22$, respectively. At the same time, Lipo246A and more so PLS-1 protein levels exceeded the weak expression of survivin in Lipo-DUE1 cells.

To further elucidate the effect of a chemical inhibition of survivin, we incubated LPS cell lines with increasing
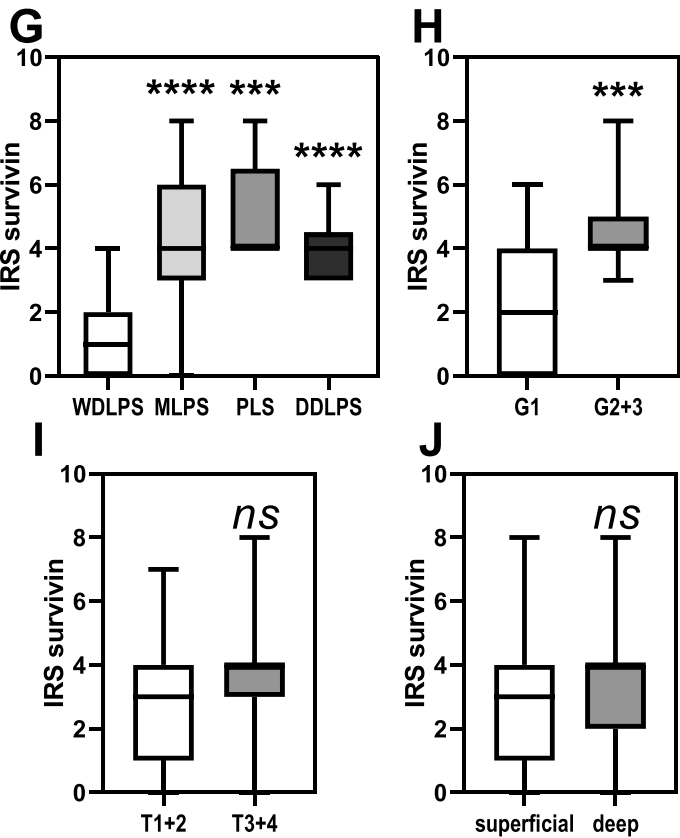

IRS values $(<3)$ correlated with G1-tumours, whereas less differentiated LPS $(\mathrm{G} 2+3)$ exclusively classed with high IRS $(\geq 3)$. I, J No significant differences in mean IRS values were apparent between grouped T-stages, or superficial versus deep localisation. DAB, 3,30-diaminobenzidine; TMA, tissue micro-array; WLDPS, well differentiated liposarcoma; MLPS, myxoid liposarcoma; PLS, pleomorphic liposarcoma; DDLPS, dedifferentiated liposarcoma; IRS, immunoreactivity score

concentrations of the small molecule antagonist YM155 for $96 \mathrm{~h}$ and measured cell viability by performing MTS assays (Fig. 3C). Incubation with YM155 resulted in a significant reduction of Lipo-DUE1, Lipo246A and PLS-1 cells in a dose-dependent manner with an IC50 of $0.15 \mu \mathrm{M}, 0.16 \mu \mathrm{M}$, and $0.03 \mu \mathrm{M}$, respectively. Of note, a decrease in survivin protein levels became evident only in the more sensitive PLS- 1 cells at $1 \mu \mathrm{M}$ (Fig. 3D). To further assess the proapoptotic potency of survivin small molecule antagonist YM155, we again incubated LPS cell lines with increasing concentrations of YM155 and determined $24 \mathrm{~h}$ later the fraction of apoptotic cells by Annexin V/PI-staining and FACS (Fig. 3E). While Lipo-DUE1 cells showed an increase of apoptotic cells significantly correlating with the amount of administered YM155 reaching $17.3 \%$ at $100 \mathrm{nM}$ and 54.8\% at a $300 \mathrm{nM}$ concentration (Kruskal-Wallis test, $p=0.0237$; Dunn-Bonferroni test, $p<0.05$ ), the treatment of Lipo246A cells with YM155 did not substantially affect the fraction of Annexin V and PI positive cells. In PLS-1 cells again, the increasing concentrations of YM155 were associated with higher proportions of apoptotic cells (Kruskal-Wallis test, $p=0.0156$; Dunn-Bonferroni test, $p<0.01$ ). 
Table 2 Correlation between survivin expression and clinicopathological markers in LPS

\begin{tabular}{|c|c|c|c|}
\hline Variables & Low, $n=16(\%)$ & High, $n=33(\%)$ & $p$ value \\
\hline \multicolumn{4}{|l|}{ Age; years } \\
\hline$<58$ & $8(50)$ & $17(51.5)$ & \multirow[t]{2}{*}{$1.000^{\dagger}$} \\
\hline$\geq 58$ & $8(50)$ & $16(48.5)$ & \\
\hline \multicolumn{4}{|l|}{ Gender } \\
\hline Male & $11(68.8)$ & $18(54.5)$ & \multirow[t]{2}{*}{$0.375^{\dagger}$} \\
\hline Female & $5(31.2)$ & $15(45.5)$ & \\
\hline \multicolumn{4}{|l|}{ Subtype } \\
\hline WDLPS & $15(93.8)$ & $3(9.1)$ & \multirow[t]{4}{*}{$<0.001^{*}$} \\
\hline MLPS & $1(6.2)$ & $16(48.5)$ & \\
\hline PLS & $0(0)$ & $5(15.1)$ & \\
\hline DDLPS & $0(0)$ & $9(27.3)$ & \\
\hline \multicolumn{4}{|l|}{ Tumour stage } \\
\hline $\mathrm{T} 1$ & $4(25)$ & $4(12.1)$ & \multirow[t]{4}{*}{$0.437 *$} \\
\hline $\mathrm{T} 2$ & $7(43.8)$ & $11(33.3)$ & \\
\hline $\mathrm{T} 3$ & $2(12.5)$ & $6(18.2)$ & \\
\hline $\mathrm{T} 4$ & $3(18.7)$ & $12(36.4)$ & \\
\hline \multicolumn{4}{|l|}{ Grade } \\
\hline G1 & $13(81.3)$ & $10(30.3)$ & \multirow[t]{4}{*}{$<0.001^{*}$} \\
\hline G2 & $0(0)$ & $10(30.3)$ & \\
\hline G3 & $0(0)$ & $13(39.4)$ & \\
\hline Undefined & $3(18.7)$ & $0(0)$ & \\
\hline \multicolumn{4}{|l|}{ Localisation } \\
\hline Superficial & $10(62.5)$ & $16(48.5)$ & \multirow[t]{2}{*}{$0.382^{\dagger}$} \\
\hline Deep & $6(37.5)$ & $17(51.5)$ & \\
\hline
\end{tabular}

$W D L P S$ well differentiated liposarcoma; $M L P S$ myxoid liposarcoma, $P L S$ pleomorph liposarcoma; DDLPS dedifferentiated liposarcoma; low IRS $<$ mean; high IRS $\geq$ mean

$\dagger$ Fisher's exact test

*Chi-square test

Next, we tested the response of LPS cell lines to the clinically established cytotoxic single-agents doxorubicin and etoposide solitarily as well as in combination with YM155 (Fig. 4).

Both, doxorubicin and etoposide induced a significant decrease in cell viability of all investigated cell lines, whereby significantly higher concentrations were necessary for the latter (Fig. 4A, B). Of note, combinational treatment of doxorubicin $(10 \mu \mathrm{M})$ with increasing concentrations of YM155 (10 nM; $30 \mathrm{nM} ; 100 \mathrm{nM}$ ) for $72 \mathrm{~h}$ demonstrated only in Lipo-DUE1 cells a synergistic effect for $10 \mathrm{nM}(\mathrm{FP}=0.64)$ of $\mathrm{YM} 155$ when administered together with doxorubicin (Fig. 4C, Supplementary Table 1). However, in Lipo-DUE1 and PLS cells treated with $10 \mu \mathrm{M}$ of etoposide, we observed a synergistic effect when combined with YM155 at nanomolar concentrations. (Fig. 4D, Supplementary Table 1).

\section{Discussion}

Due to its yet not unequivocally understood but central function in cell cycle progression, apoptosis suppression, and cell migration, survivin has been established as a marker for chemoresistance in solid neoplasia showing promise as an inventive target for molecular therapy approaches (Wheatley and Altieri 2019). While survivin expression proved to be significantly related to disease progression and patient outcome in several tumour entities, only a few studies have addressed its role in the formation and progression of LPS (LaPensee et al. 2007; Ghadimi et al. 2011; de Graaff et al. 2017).

In the present study, we investigated the characteristics of survivin expression in various liposarcoma subtypes collected from surgical specimens of 49 cases with primary LPS. For the cohort reflecting the general incidence, epidemiologic characteristics, and distribution of the respective LPS subtypes (Lee et al. 2018), the experimental results were correlated with the corresponding clinicopathological parameters including postoperative patient survival.

Residual tumour burden after resection, local recurrence, and metastasis have been described before as relevant prognostic markers in LPS as well as tumour localisation, subtype, grading, and size (Knebel et al. 2017), of which primary tumour depth and LPS subtype were identified as independent prognostic markers in the present study. In this context, DDLPS was predominantly found in deep abdominal compartments and, furthermore, high-grade tumours (G2-3) generally were larger in diameter than low-grade LPS (G1). Deep LPS localisation comprising predominantly retroperitoneal DDLPS was significantly related to a poor postoperative overall survival.

Survivin expression was determined by immunohistochemistry and evaluated according to Remmele and Stegner's immunoreactive score taking into account both the intensity of staining and the percentage of positively stained cells (Remmele and Stegner 1987). Importantly, none of the samples taken from normal fatty tissue or lipoma expressed survivin. While WDLPS almost entirely shared low survivin expression scores, DDLPS, MLPS, and PLS consistently exhibited high levels of cytoplasmic as well as nuclear survivin closely corresponding with previously published series (Ghadimi et al. 2011; de Graaff et al. 2017). In addition, in our study the degree of survivin expression significantly reflected the tumour grading with $81.3 \%$ of the low-grade tumours (G1) showing low and $100 \%$ of high-grade tumours (G2-3) expressing high levels. Mean overall survival among patients with high level expression ranged below the average of the cohort reducing the 5-year-survival rates from $79 \%$ 
Fig. 2 Overall survival of liposarcoma (LPS) patients according to survivin expression and clinicopathological variables. Kaplan-Meier survival curves illustrating the prognostic values of A survivin expression, B localisation, C LPS subtype, D tumour grading, E primary tumour depth (T-stage), and $\mathbf{F}$ tumour size. IRS, immunoreactivity score; WLDPS, well differentiated liposarcoma; MLPS, myxoid liposarcoma; PLS, pleomorphic liposarcoma; DDLPS, dedifferentiated liposarcoma
A

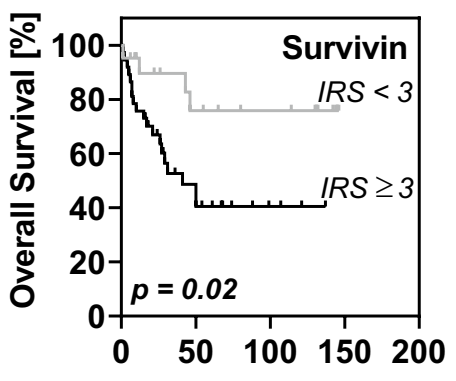

C

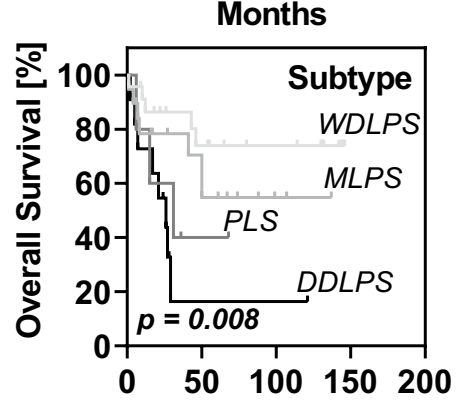

$\mathbf{E}$

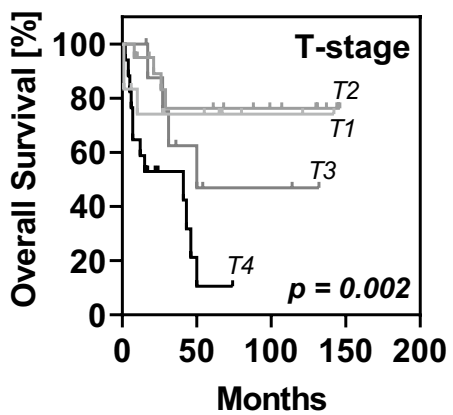

B

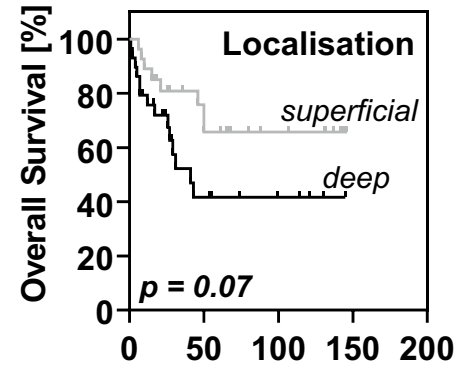

D

Months

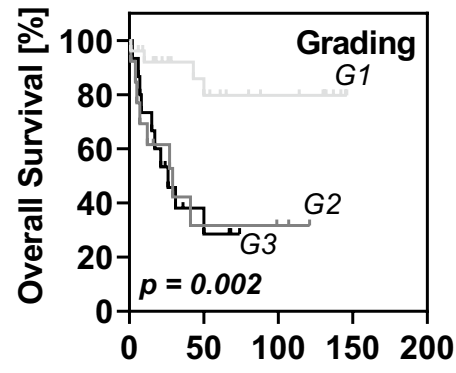

$\mathbf{F}$

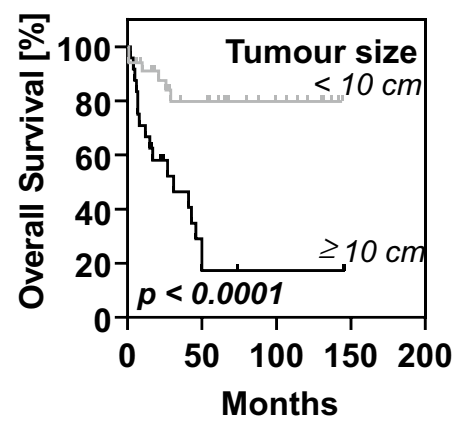

Table 3 Overall survival analysis

\begin{tabular}{|c|c|c|c|}
\hline Variables & HR & CI (lower-upper 95\%) & $p$ value \\
\hline \multicolumn{4}{|c|}{ Univariate survival analysis } \\
\hline Age at surgery & 2.318 & $0.869-6.183$ & 0.093 \\
\hline Sex & 0.949 & $0.368-2.451$ & 0.914 \\
\hline Subtype & 1.960 & $1.289-2.980$ & 0.002 \\
\hline $\mathrm{T} 1 / 2$ vs. T3/4 & 4.063 & $1.437-11.490$ & 0.008 \\
\hline Grade (G1 vs. G2/3) & 6.389 & $1.825-22.364$ & 0.004 \\
\hline $\begin{array}{l}\text { Localisation (superfi- } \\
\text { cial vs. deep) }\end{array}$ & 1.805 & $0.707-4.607$ & 0.217 \\
\hline Survivin expression & 5.307 & $1.215-23.192$ & $\mathbf{0 . 0 2 7}$ \\
\hline \multicolumn{4}{|c|}{ Multivariate survival analysis } \\
\hline T1/2 vs. T3/4 & 4.391 & $1.479-13.036$ & 0.008 \\
\hline Subtype & 2.257 & $1.380-3.691$ & 0.001 \\
\hline
\end{tabular}

$C I$ confidence interval; $H R$ hazard ratio

$p<0.05$ indicates statistical significance

in patients with low survivin expression levels compared to $44 \%$ with high expression in their primary tumours.
While grading and survivin expression showed significance only in univariate analyses with respect to postoperative overall survival, the primary tumour depth as reflected by T stage and LPS subtype represented independent prognostic markers in the analysed cohort.

Beyond immunostaining for cellular survivin protein expression in primary liposarcoma subtypes, the expression of survivin was quantified in three LPS cell lines by qPCR on mRNA levels as well as by western blotting on protein levels: while the DDLPS cell line Lipo-DUE1 was characterized by high RNA-levels of survivin and low protein-levels - presumably due to post translational modifications - the two other cell lines Lipo246A (DDLPS) and PLS-1 (PLS) exhibiting only low to moderate survivin RNA levels impressed with substantially higher amounts of survivin protein expression.

Among the known survivin interacting agents, we chose the imidazolium compound sepantronium bromide (YM155), which supresses the survivin core promotor activity by disrupting the survivin binding ILF3/p54 complex and Sp1-DNA interaction required for survivin expression 
Fig. 3 Antagonistic effects of sepantronium bromide (YM155) on survivin expression in LPS cell lines LipoDUE1, Lipo246A, and PLS-1. A Differing survivin RNA levels relative to GAPDH expression $\left(2^{-\Delta \Delta C T}\right)$ as determined by qPCR. B Western blotting indicated variant base line protein expression of survivin in Lipo-DUE1, Lipo246A, and PLS-1. GAPDH expression served as a reference. $\mathbf{C}$ Dose-dependent cell viability decrease after $96 \mathrm{~h}$ of YM155 treatment in relation to DMSO controls with corresponding IC50 values as determined by MTS-assays. D Dose-dependent reduction of survivin protein expression by incubation with YM155 (1,000 nM) for $12 \mathrm{~h}$ was detectable only in PLS-1 cells as shown by western blotting compared to DMSO vehicle controls and in relation to GAPDH. E Percentage ranges of apoptotic cells after $48 \mathrm{~h}$ of YM155 treatment determined by FACS analyses: YM155 exerts significant apoptotic effects on Lipo-DUE1 $(p<0.05)$ and PLS- 1 cells $(p<0.01)$ while Lipo246A cells remain largely unaffected. YM155, sepantronium bromide; LPS, liposarcoma
A
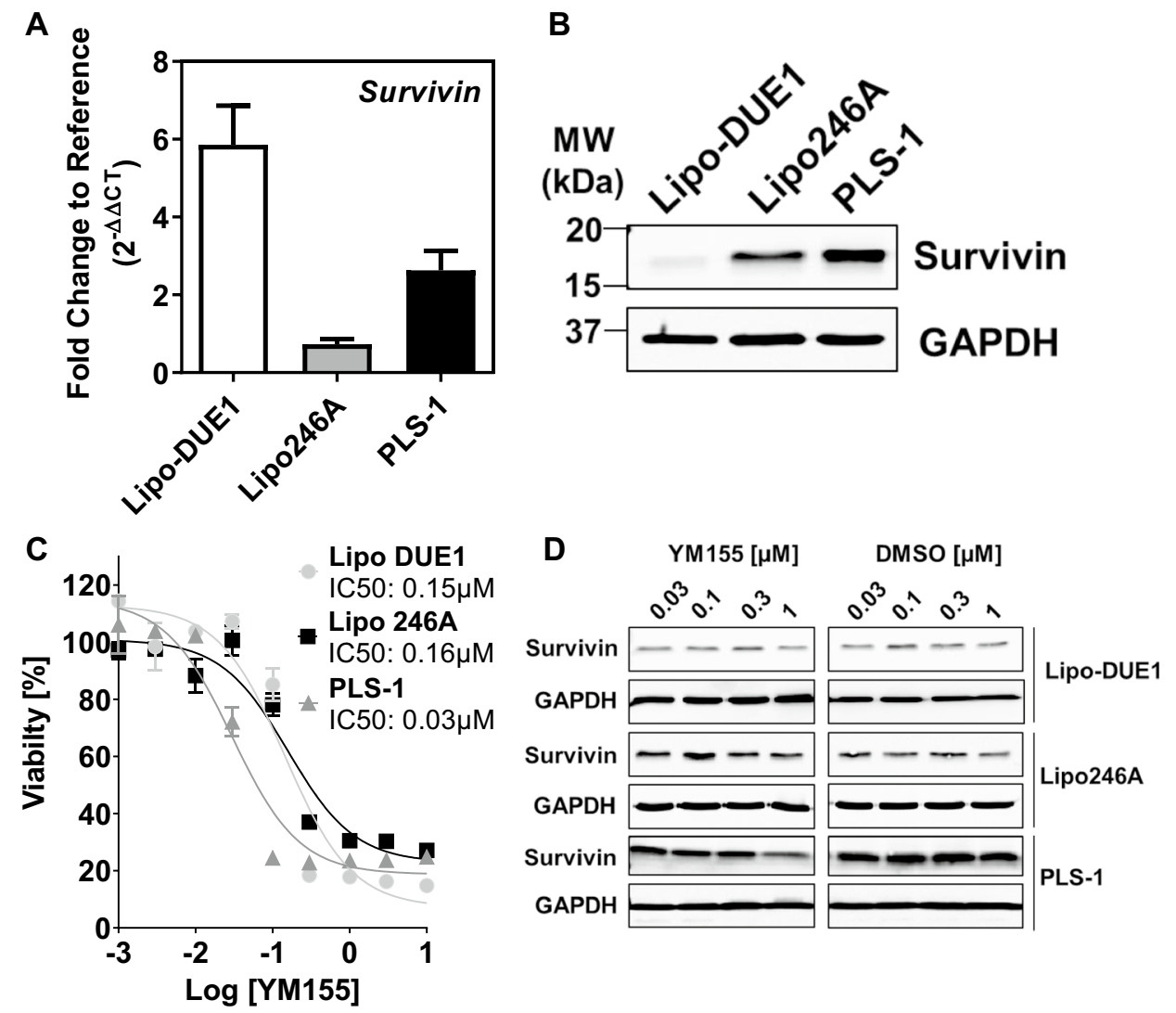

E

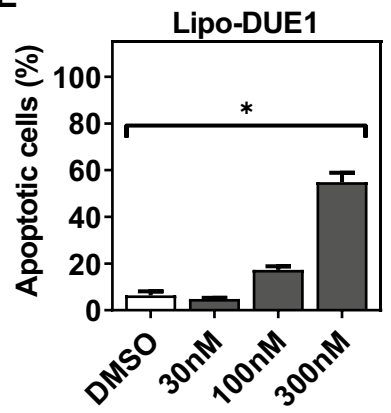

B

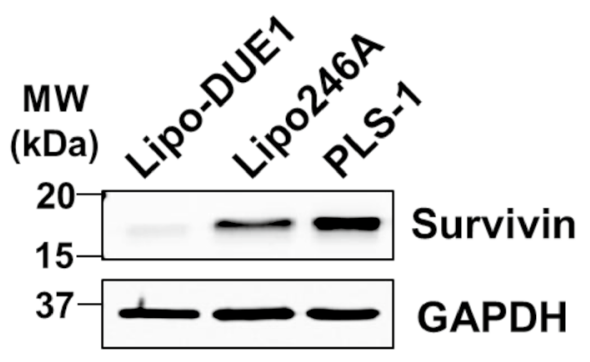

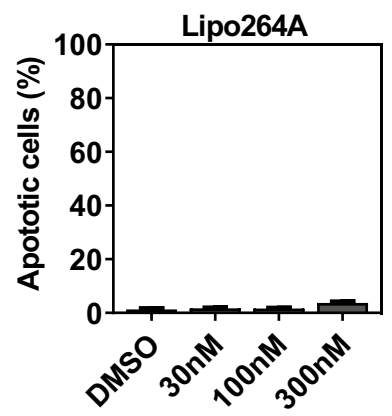

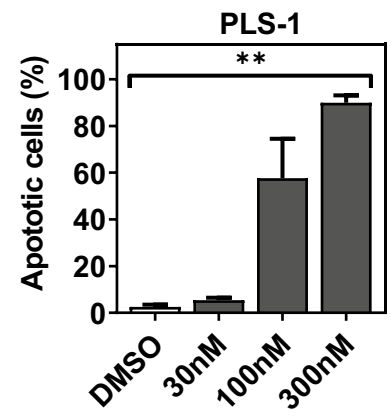

(Cheng et al. 2012; Yamauchi et al. 2012), as the most promising substance to assess its potential effectiveness in LPS. The usefulness of YM155 in soft tissue sarcoma had been described before for human malignant peripheral nerve sheath tumours, MLPS and osteosarcoma (Ghadimi et al. 2012; Zhang et al. 2016; de Graaff et al. 2017). Our experimental treatment of three LPS cell lines with YM155 effectively resulted in significant reductions of cell viability in DDLPS and PLS cell lines already by nanomolar concentrations, even though protein levels were only perceptibly decreased in PLS-1 cells. Analogously, effective suppression of tumour cell growth by YM155 has been described before for MLPS cells sharing strong nuclear aggregations of survivin as the administration of YM155 resulted in a $70-90 \%$ decrease of viable cells in two of three cell lines assessed (de Graaff et al. 2017). Apoptosis, however, had not been induced in MLPS by YM155.

Determining the fraction of Annexin V/PI positive cells after YM155 exposition revealed that in the cell lines LipoDUE1 and, particularly, in PLS-1 the percentage of apoptotic cells significantly rose to more than $55 \%$ and $90 \%$, respectively. In contrast, YM155 treatment of Lipo246A cells did not enhance apoptosis in a considerable proportion of cells.

Treatment of the three cell lines with the LPS approved chemotherapeutic agents doxorubicin and etoposide (Tacar et al. 2013), respectively, resulted in a significant dosedependent reduction of viable tumour cells up to $50-70 \%$. This effect had been demonstrated similarly for the metastatic liposarcoma cell line SW872 (LaPensee et al. 2007) treated with doxorubicin resulting in a decrease of 
Fig. 4 Synergistic effect of chemotherapeutic agents and survivin inhibitor YM155 in LPS cell lines. LPS cell viability by MTS assay after $96 \mathrm{~h}$ of treatment with A doxorubicin and $\mathbf{B}$ etoposide in various concentrations $(0.01 \mu \mathrm{M} ; 0.03 \mu \mathrm{M}$; $0.1 \mu \mathrm{M} ; 0.3 \mu \mathrm{M} ; 1 \mu \mathrm{M} ; 3 \mu \mathrm{M}$; $10 \mu \mathrm{M}$ ) with IC50 values depicted: Increasing concentrations resulted in significant reductions of cell viability rates with uniform results for LipoDUE-1, Lipo246A, and PLS-1 cells during doxorubicin treatment. MTS assays for LPS cell lines treated with $\mathbf{C}$ doxorubicin $10 \mu \mathrm{M}$ and $\mathbf{D}$ etoposide $10 \mu \mathrm{M}$ in combination with YM155 in rising concentrations $(0.01 \mu \mathrm{M} ; 0.03 \mu \mathrm{M}$; $0.1 \mu \mathrm{M}$ ) for $72 \mathrm{~h}$. As indicated by asterisks, the fractional products (FP) between expected (cell viability calculated from simply adding up the effects of the single agents doxorubicin or etoposide and YM155) and measured viability rates of Lipo-DUE1 (DDLPS) cells indicate relevant sensitisation effects for combined treatment with YM155 and doxorubicin or etoposide (*indicates $p<0.05$ ). YM155, sepantronium bromide; LPS, liposarcoma; DDLPS, dedifferentiated liposarcoma
A

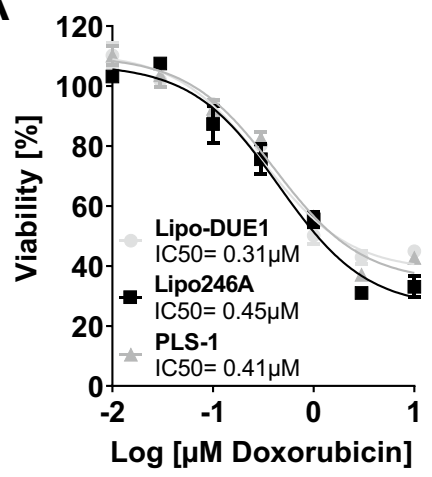

B

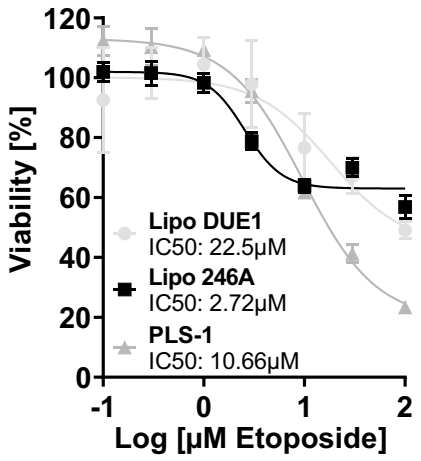

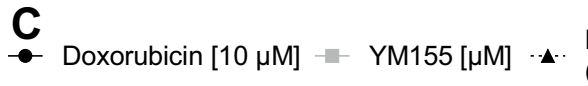
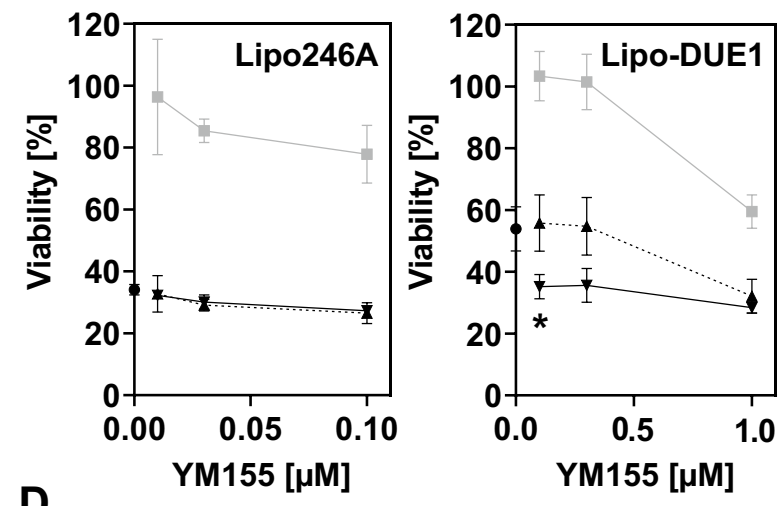

Expected viability
Measured viability
(Doxorubicin + YM155)

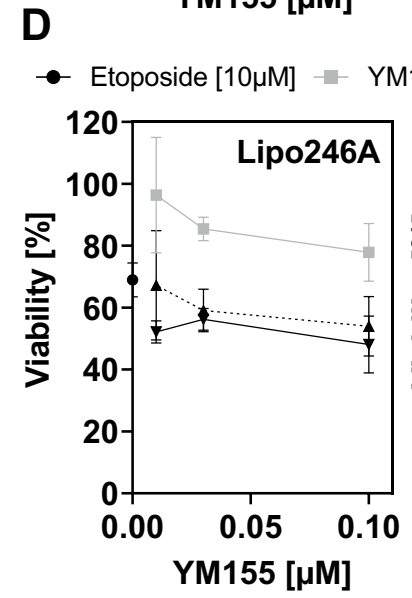

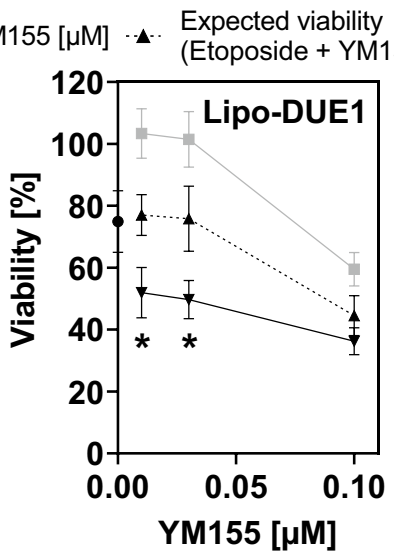
M155)
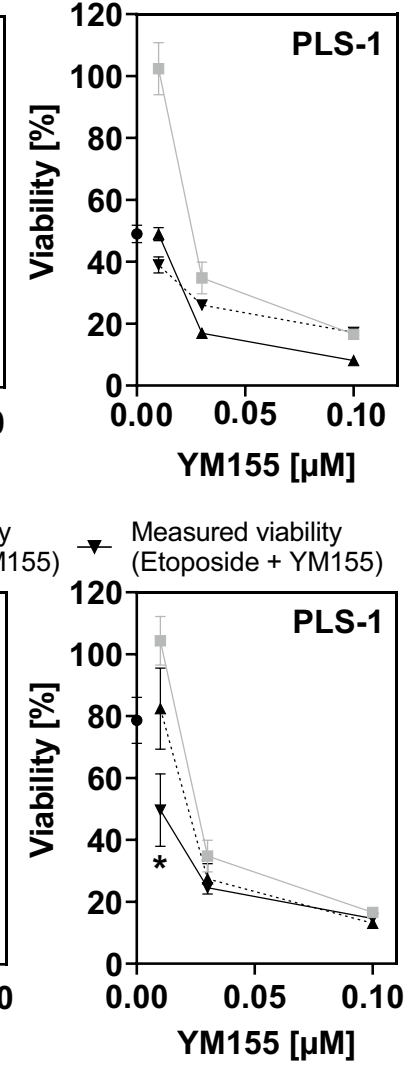

cell viability of $80-90 \%$ and MLPS cell lines (402,091; $1,765,092$; DL-221) with a cell-death induction rate of more than $80 \%$ (de Graaff et al. 2017). Clinically, as far as $44 \%$ of MLPS patients may respond to doxorubicin (Patel et al. 1994), whereas PLS patients have not demonstrated prognostic improvements after single anthracycline treatment (Eilber et al. 2004). In line with the observation that YM155-mediated decrease of survivin activity has attenuated chemoresistance in other malignancies (Koike et al. 2014; Guo et al. 2015), in the present study combined treatment of doxorubicin and etoposide with YM155 demonstrated a drug-depending synergistic effect in the DDLPS Lipo-DUE1 as well as the pleomorphic PLS-1 cell lines at low concentrations of YM155. The impressive reduction of tumour cell viability and the anti-apoptotic effects of single agent YM155 in DDLPS and PLS cells as well as the potential function as a drug sensitizer challenged in our experiments highlights its potential of targeting survivin in LPS. Of note, the safety and therapeutic efficacy of dendritic cells expressing recombinant survivin are now under investigation in high-risk soft tissue sarcoma in a phase I/II clinical trial (NCT01898663). Another active phase I clinical trial targets survivin by cytotoxic T-lymphocytes in rhabdomyosarcoma (NCT02239861).

Notwithstanding the limitations of the study inter alia its retrospective design and the absence of in-vivo 
experiments, our findings underscore the potential role of survivin in the oncogenesis and progression of the distinct LPS subtypes providing a rationale to target survivin in appropriate LPS in-vivo models. Its almost exclusive presence with significant expression levels in tumour tissues maintains the special attractiveness of survivin for targeted therapy approaches in LPS as in other malignancies.

\section{Conclusion}

In this study we demonstrated that survivin expression correlated with tumour subtype and grading in LPS. In addition, we showed the effect of survivin inhibitor YM155 on DDLPS and PLS viability. Importantly, a combination of doxorubicin or etoposide with YM155 synergistically enhanced the cytotoxic effects on DDLPS and PLS cells. Thus, our results further endorse the pre-clinical advancement of novel compounds and warrant clinical applications of promising survivin-specific substances to investigate their therapeutic efficacy in LPS patients prospectively.

Supplementary Information The online version contains supplementary material available at https://doi.org/10.1007/s00432-021-03871-5.

Acknowledgements We thank Dina Lev for her kind donation of DDLPS cell line Lipo246A and PLS cell line PLS-1.

Authors' contributions AK, CV, PMS, LD, and WTK designed the study. AK, CV, LD, MPHG, IE, and WTK were responsible for patient recruitment and provided the tissue specimens. AK, PMS, and LD designed and performed the experiments. CV, PMS, LD, and AK performed the data analysis. CV and AK drafted and wrote the manuscript. LD, MPHG, IE, and WTK critically reviewed and improved the manuscript.

Funding Open Access funding enabled and organized by Projekt DEAL. No funding was received.

Availability of data and material The datasets used and/or analysed during the current study are available from the corresponding author on reasonable request.

Code availability Not applicable.

\section{Declarations}

Conflict of interest The authors declare no competing interests.

Ethical approval and consent to participate The study was approved by the local ethics committee at the Medical Faculty of the HeinrichHeine-University Duesseldorf, Germany (institutional board review no. 3821), and carried out in accordance with good clinical practice and the Declaration of Helsinki.

Consent for publication All authors declare their consent for publication. The manuscript does not contain any material that could be overtly or indirectly linked to any individual person; all data had been anonymised.
Open Access This article is licensed under a Creative Commons Attribution 4.0 International License, which permits use, sharing, adaptation, distribution and reproduction in any medium or format, as long as you give appropriate credit to the original author(s) and the source, provide a link to the Creative Commons licence, and indicate if changes were made. The images or other third party material in this article are included in the article's Creative Commons licence, unless indicated otherwise in a credit line to the material. If material is not included in the article's Creative Commons licence and your intended use is not permitted by statutory regulation or exceeds the permitted use, you will need to obtain permission directly from the copyright holder. To view a copy of this licence, visit http://creativecommons.org/licenses/by/4.0/.

\section{References}

Ambrosini G, Adida C, Altieri DC (1997) A novel anti-apoptosis gene, survivin, expressed in cancer and lymphoma. Nat Med 3:917-921. https://doi.org/10.1038/nm0897-917

Anaya DA, Lahat G, Liu J, Xing Y, Cormier JN, Pisters PW, Lev DC, Pollock RE (2009) Multifocality in retroperitoneal sarcoma: a prognostic factor critical to surgical decision-making. Ann Surg 249:137-142. https://doi.org/10.1097/SLA.0b013e3181928f2f

Barretina J, Taylor BS, Banerji S, Ramos AH, Lagos-Quintana M, Decarolis PL, Shah K, Socci ND, Weir BA, Ho A, Chiang DY, Reva B, Mermel CH, Getz G, Antipin Y, Beroukhim R, Major JE, Hatton C, Nicoletti R, Hanna M, Sharpe T, Fennell TJ, Cibulskis K, Onofrio RC, Saito T, Shukla N, Lau C, Nelander S, Silver SJ, Sougnez C, Viale A, Winckler W, Maki RG, Garraway LA, Lash A, Greulich H, Root DE, Sellers WR, Schwartz GK, Antonescu CR, Lander ES, Varmus HE, Ladanyi M, Sander C, Meyerson M, Singer S (2010) Subtype-specific genomic alterations define new targets for soft-tissue sarcoma therapy. Nat Genet 42:715-721. https://doi.org/10.1038/ng.619

Brany D, Dvorska D, Slavik P, Skolka R, Adamkov M (2017) Survivin and gynaecological tumours. Pathol Res Pract 213:295-300. https://doi.org/10.1016/j.prp.2017.02.009

Byun SS, Yeo WG, Lee SE, Lee E (2007) Expression of survivin in renal cell carcinomas: association with pathologic features and clinical outcome. Urology 69:34-37. https://doi.org/10.1016/j. urology.2006.09.024

Cheng Q, Ling X, Haller A, Nakahara T, Yamanaka K, Kita A, Koutoku H, Takeuchi M, Brattain MG, Li F (2012) Suppression of survivin promoter activity by YM155 involves disruption of Sp1DNA interaction in the survivin core promoter. Int J Biochem Mol Biol 3:179-197

Crago AM, Brennan MF (2015) Principles in management of soft tissue sarcoma. Adv Surg 49:107-122. https://doi.org/10.1016/j. yasu.2015.04.002

Crago AM, Dickson MA (2016) Liposarcoma: multimodality management and future targeted therapies. Surg Oncol Clin N Am 25:761-773. https://doi.org/10.1016/j.soc.2016.05.007

Crago AM, Socci ND, DeCarolis P, O’Connor R, Taylor BS, Qin LX, Antonescu CR, Singer S (2012) Copy number losses define subgroups of dedifferentiated liposarcoma with poor prognosis and genomic instability. Clin Cancer Res 18:1334-1340. https://doi. org/10.1158/1078-0432.CCR-11-2820

Dalal KM, Kattan MW, Antonescu CR, Brennan MF, Singer S (2006) Subtype specific prognostic nomogram for patients with primary liposarcoma of the retroperitoneum, extremity, or trunk. Ann Surg 244:381-391. https://doi.org/10.1097/01.sla.0000234795.98607. 00

de Graaff MA, Malu S, Guardiola I, Kruisselbrink AB, de Jong Y, Corver WE, Gelderblom H, Hwu P, Nielsen TO, Lazar AJ, Somaiah 
N, Bovee J (2017) High-throughput screening of myxoid liposarcoma cell lines: survivin is essential for tumor growth. Transl Oncol 10:546-554. https://doi.org/10.1016/j.tranon.2017.05.007

Dizdar L, Oesterwind KA, Riemer JC, Werner TA, Mersch S, Mohlendick B, Schutte SC, Verde PE, Raba K, Topp SA, Stoecklein NH, Esposito I, Knoefel WT, Krieg A (2017a) Preclinical assesement of survivin and XIAP as prognostic biomarkers and therapeutic targets in gastroenteropancreatic neuroendocrine neoplasia. Oncotarget 8:8369-8382. https://doi.org/10.18632/oncotarget.14207

Dizdar L, Tomczak M, Werner TA, Safi SA, Riemer JC, Verde PE, Stoecklein NH, Knoefel WT, Krieg A (2017b) Survivin and XIAP expression in distinct tumor compartments of surgically resected gastric cancer: XIAP as a prognostic marker in diffuse and mixed type adenocarcinomas. Oncol Lett 14:6847-6856. https://doi.org/ 10.3892/ol.2017.6999

Dizdar L, Junemann LM, Werner TA, Verde PE, Baldus SE, Stoecklein NH, Knoefel WT, Krieg A (2018) Clinicopathological and functional implications of the inhibitor of apoptosis proteins survivin and XIAP in esophageal cancer. Oncol Lett 15:3779-3789. https:// doi.org/10.3892/ol.2018.7755

Eilber FC, Eilber FR, Eckardt J, Rosen G, Riedel E, Maki RG, Brennan MF, Singer S (2004) The impact of chemotherapy on the survival of patients with high-grade primary extremity liposarcoma. Ann Surg 240:686-695. https://doi.org/10.1097/01.sla.0000141710. $74073.0 \mathrm{~d}$

Ghadimi MP, Liu P, Peng T, Bolshakov S, Young ED, Torres KE, Colombo C, Hoffman A, Broccoli D, Hornick JL, Lazar AJ, Pisters P, Pollock RE, Lev D (2011) Pleomorphic liposarcoma: clinical observations and molecular variables. Cancer 117:5359-5369. https://doi.org/10.1002/cncr.26195

Ghadimi MP, Young ED, Belousov R, Zhang Y, Lopez G, Lusby K, Kivlin C, Demicco EG, Creighton CJ, Lazar AJ, Pollock RE, Lev D (2012) Survivin is a viable target for the treatment of malignant peripheral nerve sheath tumors. Clin Cancer Res 18:2545-2557. https://doi.org/10.1158/1078-0432.CCR-11-2592

Guo H, Wang Y, Song T, Xin T, Zheng Z, Zhong P, Zhang X (2015) Silencing of survivin using YM155 inhibits invasion and suppresses proliferation in glioma cells. Cell Biochem Biophys 71:587-593. https://doi.org/10.1007/s12013-014-0238-4

Hingorani P, Dickman P, Garcia-Filion P, White-Collins A, Kolb EA, Azorsa DO (2013) BIRC5 expression is a poor prognostic marker in Ewing sarcoma. Pediatr Blood Cancer 60:35-40. https://doi. org/10.1002/pbc. 24290

Italiano A, Toulmonde M, Cioffi A, Penel N, Isambert N, Bompas E, Duffaud F, Patrikidou A, Lortal B, Le Cesne A, Blay JY, Maki RG, Schwartz GK, Antonescu CR, Singer S, Coindre JM, Bui B (2012) Advanced well-differentiated/dedifferentiated liposarcomas: role of chemotherapy and survival. Ann Oncol 23:16011607. https://doi.org/10.1093/annonc/mdr485

Kanwar JR, Kamalapuram SK, Kanwar RK (2013) Survivin signaling in clinical oncology: a multifaceted dragon. Med Res Rev 33:765-789. https://doi.org/10.1002/med.21264

Kappler M, Kotzsch M, Bartel F, Fussel S, Lautenschlager C, Schmidt U, Wurl P, Bache M, Schmidt H, Taubert H, Meye A (2003) Elevated expression level of survivin protein in soft-tissue sarcomas is a strong independent predictor of survival. Clin Cancer Res 9:1098-1104

Knebel C, Lenze U, Pohlig F, Lenze F, Harrasser N, Suren C, Breitenbach J, Rechl H, von Eisenhart-Rothe R, Muhlhofer HML (2017) Prognostic factors and outcome of Liposarcoma patients: a retrospective evaluation over 15 years. BMC Cancer 17:410. https://doi.org/10.1186/s12885-017-3398-y

Koike H, Nitta T, Sekine Y, Arai S, Furuya Y, Nomura M, Matsui H, Shibata Y, Ito K, Oyama T, Suzuki K (2014) YM155 reverses rapamycin resistance in renal cancer by decreasing survivin. $\mathrm{J}$
Cancer Res Clin Oncol 140:1705-1713. https://doi.org/10.1007/ s00432-014-1734-z

Kooby DA, Antonescu CR, Brennan MF, Singer S (2004) Atypical lipomatous tumor/well-differentiated liposarcoma of the extremity and trunk wall: importance of histological subtype with treatment recommendations. Ann Surg Oncol 11:78-84. https://doi.org/10. 1007/BF02524350

Krieg A, Baseras B, Tomczak M, Verde PE, Stoecklein NH, Knoefel WT (2013a) Role of survivin as prognostic and clinicopathological marker in gastric cancer: a meta-analysis. Mol Biol Rep 40:5501-5511. https://doi.org/10.1007/s11033-013-2650-z

Krieg A, Werner TA, Verde PE, Stoecklein NH, Knoefel WT (2013b) Prognostic and clinicopathological significance of survivin in colorectal cancer: a meta-analysis. PLoS ONE 8:e65338. https:// doi.org/10.1371/journal.pone.0065338

LaPensee EW, Reddy SP, Hugo ER, Schwemberger SJ, Ben-Jonathan N (2007) LS14 cells: a model for chemoresistance in liposarcoma. Cancer Biol Ther 6:519-524. https://doi.org/10.4161/cbt.6.4.3816

Lee AT, Pollack SM, Huang P, Jones RL (2017) Phase III soft tissue sarcoma trials: success or failure? Curr Treat Options Oncol 18:19. https://doi.org/10.1007/s11864-017-0457-1

Lee ATJ, Thway K, Huang PH, Jones RL (2018) Clinical and molecular spectrum of liposarcoma. J Clin Oncol 36:151-159. https://doi. org/10.1200/JCO.2017.74.9598

Livak KJ, Schmittgen TD (2001) Analysis of relative gene expression data using real-time quantitative PCR and the 2(-Delta Delta C(T)) Method. Methods 25:402-408. https://doi.org/10.1006/ meth.2001.1262

Lusby K, Savannah KB, Demicco EG, Zhang Y, Ghadimi MP, Young ED, Colombo C, Lam R, Dogan TE, Hornick JL, Lazar AJ, Hunt KK, Anderson ML, Creighton CJ, Lev D, Pollock RE (2013) Uterine leiomyosarcoma management, outcome, and associated molecular biomarkers: a single institution's experience. Ann Surg Oncol 20:2364-2372. https://doi.org/10.1245/s10434-012-2834-0

Mahotka C, Krieg T, Krieg A, Wenzel M, Suschek CV, Heydthausen M, Gabbert HE, Gerharz CD (2002) Distinct in vivo expression patterns of survivin splice variants in renal cell carcinomas. Int $\mathrm{J}$ Cancer 100:30-36. https://doi.org/10.1002/ijc.10450

McKenzie JA, Grossman D (2012) Role of the apoptotic and mitotic regulator survivin in melanoma. Anticancer Res 32:397-404

Mersch S, Riemer JC, Schlunder PM, Ghadimi MP, Ashmawy H, Mohlendick B, Topp SA, Arent T, Kropil P, Stoecklein NH, Gabbert HE, Knoefel WT, Krieg A (2016) Peritoneal sarcomatosis: site of origin for the establishment of an in vitro and in vivo cell line model to study therapeutic resistance in dedifferentiated liposarcoma. Tumour Biol 37:2341-2351. https://doi.org/10.1007/ s13277-015-4050-6

Packeisen J, Korsching E, Herbst H, Boecker W, Buerger H (2003) Demystified...tissue microarray technology. Mol Pathol 56:198204. https://doi.org/10.1136/mp.56.4.198

Park JO, Qin LX, Prete FP, Antonescu C, Brennan MF, Singer S (2009) Predicting outcome by growth rate of locally recurrent retroperitoneal liposarcoma: the one centimeter per month rule. Ann Surg 250:977-982. https://doi.org/10.1097/sla.0b013e3181b2468b

Patel SR, Burgess MA, Plager C, Papadopoulos NE, Linke KA, Benjamin RS (1994) Myxoid liposarcoma. Experience with chemotherapy. Cancer 74:1265-1269. https://doi.org/10.1002/10970142(19940815)74:4\%3c1265::aid-cncr2820740414\%3e3.0. co; $2-\mathrm{x}$

Peery RC, Liu JY, Zhang JT (2017) Targeting survivin for therapeutic discovery: past, present, and future promises. Drug Discov Today 22:1466-1477. https://doi.org/10.1016/j.drudis.2017.05.009

Remmele W, Stegner HE (1987) Recommendation for uniform definition of an immunoreactive score (IRS) for immunohistochemical 
estrogen receptor detection (ER-ICA) in breast cancer tissue. Pathologe 8:138-140

Span PN, Sweep FC, Wiegerinck ET, Tjan-Heijnen VC, Manders P, Beex LV, de Kok JB (2004) Survivin is an independent prognostic marker for risk stratification of breast cancer patients. Clin Chem 50:1986-1993. https://doi.org/10.1373/clinchem.2004.039149

Tacar O, Sriamornsak P, Dass CR (2013) Doxorubicin: an update on anticancer molecular action, toxicity and novel drug delivery systems. J Pharm Pharmacol 65:157-170. https://doi.org/10.1111/j. 2042-7158.2012.01567.x

Webb JL (1963) Effect of more than one inhibitor. Enzymes and metabolic inhibitors. Academic Press, New York

Werner TA, Tamkan-Olcek Y, Dizdar L, Riemer JC, Wolf A, Cupisti K, Verde PE, Knoefel WT, Krieg A (2016) Survivin and XIAP: two valuable biomarkers in medullary thyroid carcinoma. Br J Cancer 114:427-434. https://doi.org/10.1038/bjc.2016.5

Werner TA, Dizdar L, Nolten I, Riemer JC, Mersch S, Schutte SC, Driemel C, Verde PE, Raba K, Topp SA, Schott M, Knoefel WT, Krieg A (2017) Survivin and XIAP - two potential biological targets in follicular thyroid carcinoma. Sci Rep 7:11383. https://doi. org/10.1038/s41598-017-11426-3

Wheatley SP, Altieri DC (2019) Survivin at a glance. J Cell Sci. https:// doi.org/10.1242/jcs.223826
World Medical Association (2013) World Medical Association Declaration of Helsinki: ethical principles for medical research involving human subjects. JAMA 310:2191-2194. https://doi.org/10. 1001/jama.2013.281053

Yamauchi T, Nakamura N, Hiramoto M, Yuri M, Yokota H, Naitou M, Takeuchi M, Yamanaka K, Kita A, Nakahara T, Kinoyama I, Matsuhisa A, Kaneko N, Koutoku H, Sasamata M, Kobori M, Katou M, Tawara S, Kawabata S, Furuichi K (2012) Sepantronium bromide (YM155) induces disruption of the ILF3/p54(nrb) complex, which is required for survivin expression. Biochem Biophys Res Commun 425:711-716. https://doi.org/10.1016/j.bbrc.2012. 07.103

Zhang S, Wang X, Gu Z, Wang L (2016) Small molecule survivin inhibitor YM155 displays potent activity against human osteosarcoma cells. Cancer Invest 34:401-407. https://doi.org/10.1080/ 07357907.2016.1212205

Publisher's Note Springer Nature remains neutral with regard to jurisdictional claims in published maps and institutional affiliations. 